\title{
Financial Crisis and the Ethics of Moral Hazard
}

\author{
Rutger Claassen
}

\begin{abstract}
The 2008 global financial crisis raises ethical as much as financial questions. Moral outrage centered on the imbalance between banks (too big to fail) profiting from excessive risk-taking in good times and taxpayers suffering the costs in bad times. The paper analyzes this imbalance in terms of ethical theory. It first develops a rights-based framework to answer questions about the moral obligations of states and banks towards each other. It then criticizes standard economic thinking, which de-moralizes the phenomenon of moral hazard. Moral hazard between states and banks arises in a context that cannot be interpreted as normal economic contracting, but should rather be characterized as governed by an implicit social contract giving rise to moral obligations.
\end{abstract}

Keywords: financial crisis; banks; moral hazard; ethics of risk; social contract

\section{Introduction}

It has often been said that financial crisis is as much a "moral crisis" as a purely financial crisis. However, in contrast to the many economic analyses of the recent crisis, there have not been many diagnoses in terms of ethical theory. ${ }^{1}$ The reference to morals normally does not go beyond a

\footnotetext{
${ }^{1}$ There are few analyses of the 2008 crisis by moral and political philosophers. Exceptions include: Loren Lomasky, "Liberty after Lehman Brothers," Social Philosophy \& Policy 28, no. 2 (2011): 135-65; Richard Nielsen, "High-Leverage Finance Capitalism, the Economic Crisis, Structurally Related Ethics Issues, and Potential Reforms," Business Ethics Quarterly 20 (2010): 299-330; Johan J. Graafland and Bert W. van de Ven, "The Credit Crisis and the Moral Responsibility of Professionals in Finance," Journal of Business Ethics 103 (2011): 605-19; Alojzy Nowak and Patrick O'Sullivan, "Ethical Issues in the Policy Response to the 2008 Financial Crisis: Moral Hazard in Central Banking and the Equity of Bailout," in Patrick O'Sullivan, Mark Smith, and Mark Esposito (eds.), Business Ethics. A Critical Approach: Integrating Ethics Across the Business World (London: Routledge, 2012), pp. 147-66; John Roemer, "Ideology, Social Ethos and the Financial Crisis," Journal of Ethics 16 (2012): 273-303. See also the essays collected in Ned Dobos, Christian Barry, and Thomas Pogge (eds.), Global Financial Crisis: The Ethical Issues (London: Palgrave Macmillan, 2011). There are also recent small discussions about the ethics of access to credit: Mark Hudon, "Should Access to Credit Be a Right?" Journal of Business Ethics 84 (2009): 17-28; Ned Dobos, “The Democratization of Credit," Journal of Social Philosophy 43 (2012): 50-63. Similarly with respect to "justice in finance," see: Aaron James, Fairness in Practice (New York: Oxford University
} 
reference to the greed of bankers and traders, or their customers and shareholders. This use of the qualifier "moral" belongs to what can be called "micro-ethics": it focuses on the moral evaluation of individual behavior. It suggests that if bankers and others had behaved more virtuously, the 2008 crisis would not have occurred. This micro-focus also gives rise to certain types of solutions, such as ethics training and the development of codes of conduct. However useful this is, such a microfocus leaves out the structural features underlying the financial crisis. We need to move to a macro-level, if only because many of those directly responsible for the crisis have pointed to these structural features to explain and justify their behavior: monetary policy, government regulation, expectations of customers and shareholders, and so on.

Most people seem to think that moving to a macro-level means that we abandon a moral focus and restrict ourselves to the economics or sociology of the crisis. However, the moral evaluation of institutions is as important as the moral evaluation of individual behavior. In this paper, I will adopt such an institutional focus and propose a macro-version of the "financial-crisis-as-moral-crisis" thesis. I will do so by focusing on the legitimacy of the state bailouts of banks. Arguably, moral outrage about banks' behavior was fueled largely by the fact that others had to pay for the excessive risks taken by banks. While clear and less clear cases of moral corruption and fraud occurred in the financial sector in the run-up to the crisis, such cases also happen in other parts of commercial life as well as in the public sector. What makes the financial sector unique is the fact that taxpayers had to bleed to such a large extent for these moral failures. In other words, public anger was centered on the imbalance between those profiting from excessive risk-taking in good times and those suffering the costs of that behavior in bad times. It is this phenomenon that I will analyze in terms of ethical theory in this paper.

In focusing on an ethical evaluation of bank bailouts, I will have to generalize and leave out of consideration many differences in local circumstances. Government action in 2008 and afterwards has taken different forms in different countries. The U.S. government's Troubled Asset Relief Program, focusing on buying up toxic assets, had a different structure from the approach taken by, for instance, the government of the Netherlands, when it became owner of one of the three biggest national banks (ABN Amro) by buying up its shares. Each bailout has unique features. For example, the extent to which the groups of depositors, bond-

Press, 2012), pp. 249-84; Gabriel Wollner, "Justice in Finance: The Normative Case for an International Financial Transactions Tax," Journal of Political Philosophy 22 (2014): 458-85. For a micro-focused work on ethics in finance, see John Boatright, Ethics in Finance, 2nd ed. (Oxford: Blackwell Publishing, 2008). 
holders, and shareholders were each protected in the bailouts of Bear Stearns, Fannie Mae, or Washington Mutual differed from case to case. ${ }^{2}$ Also, the extent to which governments impose their voice in the management and control of the banks they are helping also differs markedly, with, for example, the U.K. taking a more stringent approach than the U.S. did. ${ }^{3}$ Finally, and most importantly for the purposes of this paper, the extent to which taxpayers in the end suffer for mistakes made by banks also differs. For example, at the time of writing the Dutch government plans to sell its shares in ABN Amro, but as long as this has not happened, it is unclear what the net loss will have been for taxpayers (over some other, smaller rescue operations, the government even made a net profit). I will generalize over all these differences, in order to be able to focus on the question: to the extent that taxpayers suffer for banking failures, what should be made of this in moral terms?

The focus is on both sides of the state-bank relationship and contains two central questions. First, do states have a moral obligation to bail out banks? Second, do banks have a moral obligation to prevent states from having to bail them out?

I will start with the first, relatively easier, question. I will argue that state obligations to bail out banks can be grounded in the fundamental right of citizens to an adequate standard of living. This right lies at the basis of states' concern for a well-functioning economy, and ensuring the vital functions of banks is part of this concern. The structure of justification is thus indirect, and I will show how this structure is part of a rightsbased approach to morality (section 1). The harder question is whether banks have a corresponding moral obligation, that is, not to put themselves in a situation in which such a bailout becomes necessary. I propose to analyze this question by conceptualizing the relationship between banks and states as an insurance relationship. Like other forms of insurance, this relationship is vulnerable to moral hazard. I present a "standard argument" about insurance, which holds that moral hazard is not a moral, but a purely economic, problem, which can be solved through economic means. This would lead to the conclusion that banks do not have a moral obligation to prevent bailouts (section 2).

As a next step, I criticize this standard argument, arguing that it is invalid in the context of state-bank relationships because of the systemic nature of financial risk and the compulsory nature of insurance in this context. Because banks impose risks on society as a whole, the contract with the state is not a purely economic contract, but a social contract

\footnotetext{
${ }^{2}$ Joseph Stiglitz, Freefall: America, Free Markets, and the Sinking of the World Economy (New York: W.W. Norton \& Co., 2010), p. 121.

${ }^{3}$ Ibid., p. 125.
} 
with all citizens. Correspondingly, banks $d o$ have a moral obligation to accept the terms of the social contract as it is determined by states - as representatives of citizens. This does not necessarily imply that this contract dictates adopting a low-risk profile so that a bailout will be unlikelyeverything depends on the risk profile citizens are willing to accept (section 3). This leaves open the question as to what the terms of the social contract between states and banks should be. I use an analysis of the structural causes of the events of the recent financial crisis that reveals two relevant factors: popular expectations of economic growth and justice in the distribution of wealth. These factors together determine what our moral analysis of the crisis should be: whether we should say that citizens concluded a social contract that in retrospect they can only regret; or whether banks abused their position to impose their own terms of contract on citizens against the latter's will (section 4).

\section{The Moral Justification of Bank Bailouts: Fundamental Rights}

Can bank bailouts be morally justified? To think about this question in a systematic way requires us to adopt a position in ethical theory more generally. While there are several competing theories conceptualizing the nature of our moral commitments, I will assume and adopt a rights-based approach to morality.

According to a rights-based approach, moral relations are conceptualized as a system of moral rights and corresponding obligations ("duties" and "responsibilities" in the following are used as synonymous with "obligations"). This basic focus can be philosophically defended in different ways. ${ }^{4}$ Rights-based theories generally argue for a set of fundamental rights that are owed to every person. Not every right is a fundamental right: only the weightiest rights make it to that list. In a national context, we often talk about "constitutional rights," while in the international context, the term "human rights" is most often used. ${ }^{5}$ Here I will use the more general term "fundamental rights," which is neutral with respect to these contexts. Anyone putting forward a case for a fundamental right claims that this right should be recognized in positive law and protected by relevant public authorities. The moral claim is that fundamental rights should be treated as urgent, nonoptional, and overriding other interests of lesser weight.

\footnotetext{
${ }^{4}$ For example: Ronald Dworkin, Taking Rights Seriously (Cambridge, Mass.: Harvard University Press, 1977); Alan Gewirth, Reason and Morality (Chicago: University of Chicago Press, 1978); Loren Lomasky, Persons, Rights, and the Moral Community (Oxford: Oxford University Press, 1987).

${ }^{5}$ James Griffin, On Human Rights (Oxford: Oxford University Press, 2008).
} 
From the perspective of such a rights-based theory, I propose to reconstruct the moral basis for state bailouts of banks as grounded in the social right of citizens to an adequate standard of living (e.g., article 25 of the Universal Declaration of Human Rights). ${ }^{6}$ States save banks not because banks have a fundamental right to be saved, but because citizens have a fundamental right to an adequate standard of living. Fundamental rights are always rights of individual agents. Banks are institutions, and as such can have only derivative moral value. The value of banks' continuing existence is conditional upon the (vital) function they fulfill in the economy. The justification, then, is indirect, and points to the state's responsibility for the economy as a whole, not to a concern for the intrinsic value of banks. Banks have a derivative right to be saved, derived from citizens' fundamental rights to an adequate standard of living.

This justification depends on the correctness of three specific empirical claims: (1) a well-functioning economy is necessary to uphold citizens' rights to an adequate standard of living; (2) banks fulfill a necessary function (i.e., supplying credit) in such a well-functioning economy; (3) bailouts in situations of systemic breakdown of the financial system are necessary to maintain the vital function of banks, and hence a wellfunctioning economy. While much could be said about the exact scope and content of each of these claims, for my purposes it suffices to assume that they are roughly correct, along the following lines. Banking in its most simple form depends on two types of transactions: taking in deposits from savers, and lending these deposits to borrowers who need credit. The bank's profit results from the spread on the interest between these two activities. This structure makes banks susceptible to bank runs if for some reason the confidence of savers vanishes. In these cases only central banks and/or governments can act as lenders of last resort if they want to prevent a bankruptcy. If a bank is "too big to fail," allowing bankruptcy may pose a systemic risk for the financial system as a whole, which may be disrupted, leading to severe economic crises.

\footnotetext{
${ }^{6} \mathrm{An}$ alternative is to rely on the right to private property. This requires a reformulation of this right as commonly understood. Normally, the right to property is taken to protect every citizen's claim to be a property owner, i.e., a normative status: individual humans (but not animals, or rocks) can own things as their property - and if they do, the state will protect their possession of these things against threats from others. However, the right does not include a right to actually possess specific goods, or a minimum amount of them, as property. Some have argued that from any plausible defense of the right as a status, it also follows that individuals should have some minimum amount of property: see Jeremy Waldron, The Right to Private Property (Oxford: Clarendon Press, 1988). If so, then this right would have the same implication as the right to an adequate standard of living. However, as long as this implication is not widely recognized, it is easier to refer to the right to an adequate standard of living directly.
} 
It should be emphasized that the rights claim above is conditional on the correctness of these empirical assumptions. ${ }^{7}$ This means that there is no unqualified right to a bailout. The right is restricted to those situations in which allowing a specific bank to fail would be impossible without accepting a major systemic risk to the economy as a whole. Moreover, when there is another, morally more preferable way to safeguard each citizen's right to an adequate standard of living, there is no right to a bailout either. For example, if the state could (with the same amount of money) prevent economic collapse by taking over the mortgage payments of those defaulting on their subprime mortgage, this could be a morally preferable strategy over bailing out the banks holding the mortgages.

One could object to this familiar argument by stating that bailouts are not necessary, because there are other measures that would completely eliminate these risks (which the bailouts leave intact). One can then point to proposals for radical reforms of the financial system, for example, to abolish fractional reserve banking altogether, to nationalize all banks, or to severely restrict or even prohibit the most risky banking practices (like investment banking). However, even if these measures would eliminate systemic risk, they may also be less efficient for the economy as a whole than accepting some systemic risk while at the same time trying to contain it through regulation. ${ }^{9}$ These are large and complex issues, which I cannot address here. Instead of making the comparative institutional analysis between different proposals, I will assume that it is best to accept the principles of a commercial banking system of the form that we have in present-day developed economies. That means that some measure of systemic risk will continue to be a problem, and some sort of bailout system will be needed as a response option in cases of crisis.

To get a better grip on the peculiar indirect structure of justification set out above, it may be helpful to point to a well-known phenomenon in rights theories: some rights are meant not to protect the rights-holder (as in standard cases), but instead are meant to protect the interests of a third party. Parents have certain rights, for example, to receive child benefits, because of the interests of their child to grow up under minimally decent financial circumstances. Journalists have a right to protect their sources,

\footnotetext{
${ }^{7}$ This is a big "if." Especially the third assumption is controversial. Some would argue that allowing bankruptcies better protects the right to an adequate standard of living in the long run than bailing out, given the perverse incentives of the latter.

${ }^{8}$ I thank an anonymous reviewer for pressing me to clarify this point.

${ }^{9}$ As a reviewer pointed out to me, this is a tricky business, because some forms of regulation may - by limiting competition - themselves increase the risk of a situation of "too big to fail" (as an unintended consequence). Thus forms of regulation need to be found that do not have that adverse effect.
} 
because of the interests of the public in receiving vital information. ${ }^{10}$ In these and other cases, a person may exercise a right in order to fulfill a role from which a third party is the chief beneficiary. A similar situation holds here. Banks can make a claim on the state to be saved from collapse only because (and to the extent that) they, as institutions, fulfill the vital role in the economy described above. There is nothing mysterious about such an indirect claim. The only difference with the cases of parents or journalists is that banks are institutions, not persons. This difference does not itself invalidate the indirect structure of justification. In all these cases, the indirect structure creates a relationship of dependence between both parties. Children need to trust that parents will take care of their interests. A similar relationship of trust and dependence arises between citizens and their banks.

The fact that the rights claim is about banks as institutions may lead to another confusion that needs to be avoided. ${ }^{11}$ Nothing is said here about the rights of individuals whose interests are also touched by bailouts: the bankers (employees of the banks), the capital owners (shareholders of the bank), customers (who have put their savings in the bank). Specifically, some people condemn bank bailouts on the grounds that they save bankers from the disastrous effects of their imprudent behavior. Such complaints, however understandable in the context of the recent bailouts, conceptually confuse these two issues. No inference about bankers can be drawn from the claim made here about banks. One can defend a bank bailout and simultaneously defend sanctions for individual bankers. Similarly, no claim is made here about the rights of capital holders or customers to be reimbursed by the state for their losses (if any) in the process of a bank bailout.

This distinction has implications for thinking about the right to a bank bailout. Isn't such a right still counterintuitive, given the moral outrage about these bailouts? This anger about these bailouts is best reconstructed as voicing a statement about the deservingness of banks: they didn't deserve to be bailed out. Much of the force of this claim comes from the confusion between banks (institutions) and bankers (individuals). Claims about desert normally relate to persons, not institutions. When we do attribute moral praise or blame to groups-for example, when we say that a football team deserved to win the game - we refer to the collective performance of the individuals making up those groups. If we take the deservedness claim to relate to banks as institutions, it is best to interpret it as tracking a claim about an institutional obligation: that banks have an

\footnotetext{
${ }^{10}$ Leif Wenar, "The Nature of Rights," Philosophy \& Public Affairs 33 (2005): 22352, p. 241.

${ }^{11}$ I thank Nicholas Vrousalis for pressing me to clarify this point.
} 
obligation not to put themselves into a situation in which they have to ask for a bailout. Organizations, as much as persons, can have obligations to behave responsibly, and their rights can be conditional on the performance of these obligations. An unemployed person's unemployment benefit can be conditional on fulfillment of an obligation to seek a new job. Similarly, banks would have an obligation to conduct their business in such a way as to prevent having to ask for a bailout. In both cases, the situation would then be governed by a moral system of reciprocal rights and obligations.

This conclusion is premature, however. The only thing we can conclude so far is that states have an obligation to bail out banks in situations such as those of the recent crisis, since not saving the banks would have led to a serious threat to the economy as a whole, hence to citizens' rights to an adequate standard of living. The fundamental nature of the latter's claim implies that the state cannot make bailouts conditional on fulfillment of reciprocal obligations in a situation in which the nonfulfillment of the obligation is a fait accompli. The state faces a moral dilemma: either save banks (which "rewards" them for their nonfulfillment of their obligations) or not save banks (and have citizens suffer the consequences). There is nothing special about this moral dilemma. For example, in discussions about luck egalitarianism, there is a similar dilemma about the extent to which victims of car accidents deserve to be treated when these victims have deliberately not taken out health insurance. ${ }^{12}$ In the banking case, the weightier claim is the claim of citizens on the protection of their fundamental rights. Giving priority to that claim means, against the background of the empirical assumptions made above, that we cannot afford to make endorsement of it conditional on the fulfillment of the corresponding obligation.

All of this leaves open the question as to what the content of the obligation of banks is, and whether this is best conceptualized as a moral obligation (instead of a matter of mere economic prudence). To answer that question, we need a more detailed view of the exact nature of statebank relations.

\section{The (Im)Morality of Moral Hazard}

My main proposal is to conceptualize the system of rights and obligations in state-bank relations through the analytical lens of an insurance relationship. Bailouts are only justified if they are part of a legitimate

\footnotetext{
${ }^{12}$ Elizabeth S. Anderson, "What is the Point of Equality?" Ethics 109 (1999): 287337 , p. 295.
} 
insurance scheme. ${ }^{13}$ Banking inevitably involves taking risks, and the state needs to insure banks against these risks. In this section and the next one I will work out this basic proposal, with a special emphasis on the central problem in insurance relationships: moral hazard.

To introduce the insurance focus, the analogy with social insurance may be helpful. In most welfare states, workers pay mandatory insurance premiums to be insured against social risks: unemployment premiums, healthcare and disability premiums, pension premiums. Likewise, banks should pay premiums to receive state support. Surprisingly, this aspect has received almost no attention. ${ }^{14}$ Maybe it is because there was insufficient political awareness that we do, in fact, insure banks against systemic crises, that governments have never required such an insurance premium. However, a longer view of the history of banking shows that the implicit insurance is always present. Plans for bank taxes in many countries were often temporary, and focused on requiring a contribution from banks to the costs of financial crises. Structural insurance, however, needs to be permanent and forward-looking. In the legal literature, there have been proposals for such a "Systemic Emergency Insurance Fund." 15 These facilities would be specifically targeted to cover the risks of financial crises, and would be levied in addition to existing premiums and fees regularly charged on banks to be allowed to operate in a given jurisdiction.

For all forms of insurance, moral hazard is a key problem. Insurers need to counteract moral hazard on the part of those who are insured. Insurance may cover two types of damage: damage brought about by factors beyond one's own choices, like natural catastrophes (physical hazards), and damage brought about through one's own choices (moral hazards). In contrast to physical hazard, moral hazard refers to the intentional actions of insured persons. It can be defined as "the tendency for insurance against loss to reduce incentives to prevent or minimize the cost of loss." 16 This distinction between claims that arise because of damage caused by intentional behavior by those who are insured (choice)

\footnotetext{
${ }^{13}$ For a discussion of the political legitimacy of bailouts, see Adam Levitin, "In Defense of Bailouts," The Georgetown Law Journal 99 (2011): 435-514.

${ }^{14}$ Some may want to argue that higher capital reserve requirements fulfill the same function - but these are still focused on preventing the need for government help, not on making sure that such help can be paid for out of the government insurance fund that has collected the premiums. For discussion, see Anat Admati and Martin Hellwig, The Bankers' New Clothes (Princeton: Princeton University Press, 2013).

${ }^{15}$ Jeffrey Gordon and Christopher Muller, "Confronting Financial Crisis: DoddFrank's Dangers and the Case for a Systemic Emergency Insurance Fund," Yale Journal on Regulation 28 (2011): 151-211; Michael Faure and Klaus Heine, "Insurance Against Financial Crises?" New York University Journal of Law \& Business 8 (2011): 117-50.

${ }^{16}$ Tom Baker, "On the Genealogy of Moral Hazard," Texas Law Review 75 (1996): 237-92, p. 239.
} 
and damage caused by factors beyond one's own sphere of influence (chance) is as relevant for the financial sector as it is in other forms of insurance. Moral condemnations normally only arise in the context of damage caused by intentional behavior. Imagine that, due to unforeseen circumstances, banks were to be plundered by extraterrestrial aliens once every fifty years, requiring governmental capital injections to set them back on their feet. Presumably, citizens would then not feel angry, but merely sad. These unpredictable invasions would be seen as unfortunate, quasi-natural calamities, beyond the control of bankers.

The obligation of banks mentioned in the previous section-not to put themselves into a situation in which they have to ask for a bailout - can now be specified as: banks should not form a moral hazard. ${ }^{17} \mathrm{I}$ will assume that the operationalization of this obligation can be stated in terms of levels of risk: banks should not engage in levels of risk that form a moral hazard (a more fine-grained analysis might talk about types of risks related to different types of financial products and transactions, but I will here reduce these qualitative differences to a simple quantitative continuum). The obligation of banks, then, is to abstain from excessive levels of risk-taking, for these would mean a violation (implicit or explicit) of the insurance contract. However, standard theorizing about moral hazard does not conceptualize this as a moral obligation. According to what I will call the "standard argument," morally hazardous behavior can never be classified as immoral.

This argument is nicely formulated by Benjamin Hale. Hale's argument starts from the nature of insurance. The crucial point is that insurance is meant to raise people's level of risk-taking. For example, without car insurance, driving a car would be potentially very expensive. The costs of an accident being extremely high, everyone would stop driving or drive so slowly that the speed gains of having car traffic in society would be greatly diminished. With insurance, people can drive cars while assuming a higher risk profile. ${ }^{18}$ An analogous argument can be made in the context of social risks. By insuring the accidents of modern industrial society, social insurance helped to make the development of such a society possible. ${ }^{19}$ This argument can also be applied to banking. Without a

\footnotetext{
${ }^{17}$ For discussions about moral hazard in the context of the financial crisis, see, e.g.: Karl Okamoto, "After the Bailout: Regulating Systemic Moral Hazard," University of California Law Review 57 (2009): 183-236; Kevin Dowd, "Moral Hazard and the Financial Crisis," Cato Journal 29 (2009): 141-66.

${ }^{18}$ Benjamin Hale, "What's So Moral About the Moral Hazard?" Public Affairs Quarterly 23 (2009): 1-26, p. 11.

${ }^{19}$ Deborah Stone, "Beyond Moral Hazard: Insurance as Moral Opportunity," in Tom Baker and Jonathan Simon (eds.), Embracing Risk. The Changing Culture of Insurance and Responsibility (Chicago: University of Chicago Press, 2002), chap. 3, p. 60.
} 
lender of last resort, banks cannot fulfill their inherently risky work of borrowing and lending. Insurance fulfills the purpose of getting us from a low to a higher level of risk-taking, assuming that this higher level of risktaking is socially beneficial (see Table 1).

\begin{tabular}{|l|l|l|l|}
\hline & $\begin{array}{l}\text { low levels of } \\
\text { risk-taking }\end{array}$ & $\begin{array}{l}\text { high levels of } \\
\text { risk-taking }\end{array}$ & $\begin{array}{l}\text { immoral behavior (irre- } \\
\text { spective of insurance) }\end{array}$ \\
\hline $\begin{array}{l}\text { Example of car } \\
\text { insurance }\end{array}$ & $\begin{array}{l}\text { very cautious } \\
\text { driving }\end{array}$ & normal driving & joyriding, speeding \\
\hline Response & $\begin{array}{l}\text { no insurance } \\
\text { needed }\end{array}$ & $\begin{array}{l}\text { insured against } \\
\text { loss }\end{array}$ & excluded from insurance \\
\hline
\end{tabular}

Table 1. Moral hazard: the standard argument

From the perspective of this standard argument, moral hazard is not a moral problem. Of course this does not mean that there is no morally problematic behavior under insurance. Such behavior, however, according to Hale, is immoral because of other reasons than its being the consequence of moral hazard. For example, insurance may give insured persons incentives to lie when filing an insurance claim. However, the wrongness of the moral hazard here depends on the wrongness of lying, which is morally wrong whether or not there is insurance in place. ${ }^{20}$ Such behavior should be sanctioned by expulsion from the insurance pool. Thus, all behavior under insurance is classified either as moral (and thus to be legally permitted), or as immoral (and thus to be ruled out as illegal). The fact that insured individuals assume a higher risk profile as a matter of insurance is to be expected, and is actually the very purpose of insurance. All of this assumes that we can in practice make a reasonable distinction between moral and immoral behaviors under insurance. Joyriders or persons making a habit of speeding can effectively be separated from careful drivers, and their drivers' licenses can be taken from them.

This standard argument, then, does recognize immoral behavior, but only to set it apart from the start. The response to immoral behavior is expulsion from the pool of insured persons. What we call moral hazard, by contrast, is morally acceptable behavior, for which an economic response is appropriate. Because the purpose of insurance is allowing enhanced risk-taking, it is unsurprising that individuals raise their risk profile. To the extent that this leads to more and more costly claims, several economic responses are available to the insurer. One is to raise insurance

\footnotetext{
${ }^{20}$ Hale, "What's So Moral About the Moral Hazard?" p. 9.
} 
premiums to cover the costs due to higher average levels of risk taken by the insured. At some point this will lead to a declining interest in insurance; here the insurer can search for the optimum. Two other options are either to lower coverage or to establish behavioral rules (and monitor compliance with them). In both cases, excessive risk-taking is discouraged so that prices can remain attractive - in the first case by shifting the financial burden of losses from excessive risk-taking to the individual, in the second case by external controls. Which of these three economic strategies (or mix of them) is optimal depends on the type of insurance. The important point is that each of these economic responses is clearly separated from the moral response of expulsion.

This bifurcation in moral and economic responses reflects the history of insurance. The term "moral hazard" was introduced in the nineteenth century to designate a certain class of risks for new forms of insurance, like fire insurance and life insurance. Insurance itself suffered from a moral stigma, since it was associated with gambling and crime and its acceptance depended, inter alia, on its effectiveness in dealing with moral hazard. ${ }^{21}$ Nineteenth-century insurers reacted to moral hazard in two different ways with respect to the two sources of this tendency generally distinguished at the time: character and circumstance. Some people, believed simply to have "bad characters," would use every occasion for fraudulent or careless behavior. These people were to be left without insurance. Other people were in principle believed to be of good character, but nonetheless susceptible to temptation. These people could be insured, but the insurance contract had to be structured in such a way that the temptation to moral hazard was minimized. ${ }^{22}$

In the nineteenth century, the moral lens was as important as the economic one. The best proof of this was that the standard economic solution for dealing with people of bad character, charging them higher premiums, was judged unacceptable:

Not all of life, it seems, was to be ceded to the field of Hazard. What remained to be left outside was the realm of evil crime, fraud, and the suspicious "other." Thus, nineteenthcentury life and fire insurers limited the insurance of moral hazards, not because of the complexity or for other technical reasons, but because of ideas about right and wrong, as the term "moral hazard" suggests. Insurance was a moral enterprise "deeply interested in the growth of public and private honor," and insurance men had a duty to "[g]uard against moral hazard from without" and "against moral perversion from within." Everyone in the enterprise, both insurer and insured, had an obligation to exclude the immoral. ${ }^{23}$

Over the course of time, the economic lens became more dominant and

\footnotetext{
${ }^{21}$ Baker, "On the Genealogy of Moral Hazard," pp. 255-59.

${ }^{22}$ Ibid., p. 241.

${ }^{23}$ Ibid., p. 254.
} 
eclipsed the moral lens. Nowadays economists look at moral hazard as a technical problem, to be solved by adjusting incentives so that risk is minimized: "moral hazard has become exclusively a property of insurance arrangements and not a property of the individuals who enter those arrangements." 24

The decisive step in this reduction is the description of the insured's tendency to reckless behavior as a form of rational action. Individuals weigh costs and benefits, and insurance lowers the costs of a certain loss. This gives them an incentive to be careless, with the predictable result that the insurance pool is overburdened with claims: "less loss from loss [for the individual] means more loss [for the collective]." 25 The purely economic lens, then, leads to a fine-tuning of the terms of the insurance contract so as to minimize the opportunities for careless behavior. Moral hazard is morally neutralized. However, the moral lens always remains in the background, in the sense that there will always be a category of fraudulent behavior that will be classified as immoral, illegal, and potentially criminal, which will lead to exclusion from insurance and possibly other sanctions. Any form of insurance remains dependent on this distinction. The line of legitimate insurance depends on a boundary between moral and immoral forms of risk-taking.

This is the standard argument about moral hazard. It would suggest that banks do not have a moral obligation to abstain from excessive risktaking. Apart from cases of fraud and deception, excessively risky strategies are a matter of free choice. It is up to the insurer (here the state) to respond with an economically apt response. This conclusion is in flat contradiction with the moral condemnations of banks' behavior during the recent financial crisis. Maybe these moral sentiments were mistaken; or maybe the standard argument is mistaken - at least in this context.

\section{Banking and Moral Hazard}

In this section, I will start from an analysis of the special nature of the state's insurance of banks, compared with standard forms of commercial insurance. The core of this analysis is that state insurance of banks is not voluntary. This will lead us to revise the standard picture of the legitimacy of insurance: instead of an economic contract, it is governed by a social contract between banks and the state. Violation of such a contract is immoral.

If we assume the legitimacy of a commercial banking system (see

\footnotetext{
${ }^{24}$ Ibid., p. 271.

${ }^{25}$ Ibid., p. 270.
} 
section 1), the state has no choice but to fulfill the function of lender of last resort. Because states cannot reject this role, the insurance relationship between banks and states cannot be characterized as voluntary. This is different from many other forms of insurance, which are contracted on a voluntary basis between providers and consumers. The reason for this being different in the case of banking is that the nature of the risks involved is different. Banking is subject to systemic risks for society as a whole. This term does not only refer to the systemic interdependencies between banks (such that when one collapses, others face a higher risk of collapse as well), but also to the interdependencies between the banking system as a whole and the rest of the economy. Banking failures can lead to harm not only by making taxpayers pay for their high risk-taking, but also by causing economic crises that harm consumers and workers in the economy. Admittedly, these are often the same people as taxpayers, but in a different role, and these roles need to be separated. Everyone participating in the real economy is vulnerable to systemic risks imposed by banks' excessive risk-taking. ${ }^{26}$

Voluntariness is an essential aspect of the legitimacy of market transactions - we normally assume these transactions to be legitimate when both parties willingly consented to the contract. Voluntariness is also essential to the standard argument about moral hazard. Hale remarks that assuming higher risks is not a matter of stealing from the others in the insurance pool, because

others have subjected themselves to the insurance scenarios for just the reason that we have subjected ourselves to the insurance scenario, and although it will certainly be the case that many of us increase our exposure to risk, we have done so with the tacit consent of those who participate in the risk pool. ${ }^{27}$

This passage suggests correctly that the moral neutrality of moral hazard (assumed by the standard argument) depends on the consent of all those insured. However, in the case of banking, the state cannot meaningfully consent to insurance, because it can only reject it to the detriment of those it represents - taxpayers who pay the premiums of this insurance (in the sense that they bear the costs of a bailout) and all citizens (taxpayers or not) who, in their various roles as participants in the economy, face the costs of a widespread financial crisis and economic recession.

It is important to distinguish both these groups - taxpayers and citi-

\footnotetext{
${ }^{26}$ Other forms of insurance may be subject to systemic risks as well. Fires may spread to other houses, and diseases may spread as pandemics amongst a population. If these spillovers are widespread, this may be an argument for making fire or health insurance obligatory as well.

${ }^{27}$ Hale, "What's So Moral About the Moral Hazard?" p. 18.
} 
zens. As the quote from Hale shows, insurance is premised on an identity of the pool of insured persons and the pool of premium payers. This was evidently not the case during the time of the recent bailouts. Taxpayers in fact paid the premiums to insure a small group of others (banks), not themselves. The consequence of this is that those paying for this insurance were vulnerable to those whom they insure choosing their own risk profile. The latter have no incentives to choose a package with a low risk profile (and low premiums). As we have seen from the recent financial crisis, this can be very costly indeed. Now, one may be inclined to think that if we can force banks to pay appropriate insurance premiums themselves, this problem will be solved, for then banks will have effectively internalized all the costs of the systemic risks that their activities create. Of course, it is questionable whether a full internalization is ever practically feasible. For the foreseeable future, there will probably always be an important residual risk run by the taxpayer (cf. the discussion about the adequacy of the size of the fund established by the current plans for a European Banking Union). But even if full internalization were to be possible, this would not do away with the risks for citizens at large.

For simplicity's sake, assume that, under full internalization, banks could choose any level of risks/premiums. They could choose a very high level of risk with correspondingly high premiums, or a very low level of risk with correspondingly low levels of premiums, and anything in between. They would then choose their position on this spectrum on the basis of a private calculation of maximum profits. The problem is that this package is not necessarily the package that would be chosen by citizens. Citizens would choose the package on the basis of two, competing, considerations. On the one hand, they have an interest in keeping risks/premiums sufficiently low. High premiums are a burden on banks and diminish their ability to fulfill their primary function (access to credit for consumers and businesses). The highly constrained supply of credit, which is the subject of current complaints by consumers and business, can be traced back to banks' efforts to strengthen their balances. Citizens have an interest in a well-functioning economy, and thus want banks to be able to fulfill their primary function in that economy. On the other hand, citizens have an interest in banks innovating and taking sufficiently high risks - the argument for this is analogous to the standard argument for car insurance (see section 2): insurance enables socially important higher levels of risk-taking. Without risks, there can be no financial innovation. The socially optimal balance between these two competing considerations need not be identical to the balance favored by banks.

All of this can be compared to insurance against social risks such as illness and unemployment. Here too, insurance is not optional, but citi- 
zens are required to insure against these risks (in most countries). The underlying rationale may be the kind of spillover effects that we encountered in the banking case (e.g., a social interest in a healthy work force), but there may also be other rationales (e.g., myopia in individual decisionmaking, paternalistic considerations). Whatever the reasons, once insurance becomes a coercive matter, those who have to pay the premiums are understandably angry if they feel that the insurance is being abused by those engaging in excessive risk-taking. For example, an increasing part of health costs comes from lifestyles with a very high risk of causing health costs (obesity, alcohol). Discussions about individual versus social responsibility for these costs reflect the uneven distribution of these risks in the health pool: those with healthier lifestyles pay for those with unhealthy lifestyles. These discussions are morally loaded: moral blame and stigma are addressed to the obese and alcoholics raising costs. This suggests that most people assume that their co-citizens can determine their own lifestyles. This is analogous to the moral blame directed at banks when they choose excessively high-risk profiles. ${ }^{28}$

We can now more systematically sketch the differences between the insurance contract as depicted in the standard argument, and state insurance of banking. There are three salient differences.

First, in normal insurance, the choice of the acceptable level of risk is a matter of standard economic contracting between the parties involved in an insurance contract. In such a standard situation, the insurer merely is a hub; the level of risk (and corresponding premium level) is legitimately determined by the level of risk aversion that the pool of insured persons chooses. There is no (externally determined) "morally right" risk profile in this situation - the parties involved are free to choose the level based on their willingness to accept risk. In the banking case, due to the nature of systemic risk, the insurer (the state) becomes a representative of citizens, who are not party to this contract in the narrow sense, but who cannot escape its consequences. Hence, we can justifiably say that citizens are involuntarily subjected to a coercive authority, which therefore needs to be legitimated to them via a sort of social contract. This means that citizens should have the right to decide the appropriate risk level of banking in their societies, on the basis of the two competing considerations mentioned above. In the end, both of these interests are functionally related to citizens' fundamental right to an adequate standard of living. This shows that there is a tension in the underlying economic conditions

\footnotetext{
${ }^{28}$ Note the disanalogy: in the health case, citizens (as members of the same insurance pool) are angry because they face higher premiums themselves; in the banking case, citizens as taxpayers are angry because they are, as participants in the real economy, subject to the economic risks of high-risk banking.
} 
for the fulfillment of this right. However this tension is resolved, the politically determined risk level does represent a moral interest, because of its link to the fundamental right.

Second, if the insured parties (banks), for whatever reason, manage to impose their own risk profile on the insurer (state), this is a violation of the moral obligation to accept the politically determined risk level-a violation of the social contract. They are not allowed to take excessive risks if citizens have not accepted these excessive risks according to their own calculations of what is socially best. Note that the flip side of this is that banks may take excessive risks if citizens did accept them! Excessive risk-taking is not immoral per se. It all depends on what citizens decide is the best way to organize the economy and pursue adequate standards of living for everyone. The salient difference with standard cases of insurance is that banks may behave immorally within the insurance relationship. This form of immorality is not immorality due to behavior that would be immoral outside the insurance context as well (as in the standard argument): the immoral nature of the behavior here is internal to the insurance relationship (cf. Table 2: compared to Table 1 a new, third column has been inserted to account for this).

\begin{tabular}{|l|l|l|l|l|}
\hline & $\begin{array}{l}\text { low levels of } \\
\text { risk-taking }\end{array}$ & $\begin{array}{l}\text { high levels of } \\
\text { risk-taking }\end{array}$ & $\begin{array}{l}\text { excessive levels } \\
\text { of risk-taking }\end{array}$ & $\begin{array}{l}\text { immoral be- } \\
\text { havior under } \\
\text { insurance }\end{array}$ \\
\hline $\begin{array}{l}\text { Example of } \\
\text { banking }\end{array}$ & $\begin{array}{l}\text { prudent } \\
\text { banking }\end{array}$ & $\begin{array}{l}\text { banking that led } \\
\text { to financial crisis }\end{array}$ & $\begin{array}{l}\text { fraudulent } \\
\text { banking }\end{array}$ \\
\hline Response & $\begin{array}{l}\text { no insurance } \\
\text { needed }\end{array}$ & $\begin{array}{l}\text { insured against } \\
\text { loss }\end{array}$ & $\begin{array}{l}\text { insured against } \\
\text { loss }\end{array}$ & $\begin{array}{l}\text { sanctions; but } \\
\text { still insured } \\
\text { against loss }\end{array}$ \\
\hline
\end{tabular}

Table 2. Moral hazard and banking

Third, in contrast to the standard insurance contract, the specifically moral strategy to deal with immoral behavior, expulsion, is unavailable: in cases in which banks do not fulfill their obligation, they cannot (or so we have assumed) be sanctioned by the state's refusal to bail out (see section 1). This means that the state inevitably needs to resort to the three economic strategies mentioned earlier (raising premiums, lowering coverage, monitoring and sanctioning behavior), to regulate a moral problem: how to enforce a politically determined level of risk against a party violating the contract. As in the case of social insurance, the state must 
respond to this situation by using its coercive powers to enforce the social contract. In the case of banking, this turns out to be difficult in practice, because the state often has limited opportunities to make effective use of this power. Banks almost always have a superior information position compared with regulating agencies, and can try to use that position to evade regulation. These practicalities of regulation have a highly technical nature, but this should not lead us to forget the moral nature of the enterprise of regulation.

In conclusion, the discussion of moral hazard has led us to a contractualist standard of justification for determining the legitimate level of risk-taking. It may be worth noting that the need to distinguish morally unacceptable (excessive) from acceptable (high-but-not-excessive) levels of risk-taking is well known in the literature on the ethics of risk. There it is generally accepted that the probability of a harm is not necessarily a harm itself. When a person $\mathrm{A}$ imposes a risk on person $\mathrm{B}$, he imposes a probability that B will be harmed. But if every imposition of risk would automatically qualify as a harm, no one could ever impose a risk on others. This makes risk-taking impossible: the so-called problem of paralysis. ${ }^{29} \mathrm{~A}$ reasonable alternative must balance the social costs and benefits of imposing risks. There are different competing theories to decide such a balance, and one of them is a contractualist standard: risk impositions are "justified so long as the ends that produce the risks could be endorsed by those who are subject to them." ${ }^{, 30}$ This contractualist approach to the ethics of risk is supported by the analysis given above in terms of a social contract. The legitimacy of excessive risk-taking depends on the social contract between banks and all those vulnerable to the systemic risk of banking. ${ }^{31}$

This is not the end of the matter, however, for this raises the question as to which levels of risk "could be endorsed by those who are subject to them." How does one apply this standard? Here we need to distinguish between the implications for a retrospective evaluation of the financial crisis, and for a prospective analysis of the future of the banking system. Prospectively, the general idea would be for citizens and banks to con-

\footnotetext{
${ }^{29}$ Madeleine Hayenhjelm and Jonathan Wolff, "The Moral Problem of Risk Impositions: A Survey of the Literature," European Journal of Philosophy 20, suppl. S1 (2012): E26-E51, p. E32.

${ }^{30}$ John Oberdiek, "Towards a Right Against Risking," Law and Philosophy 28 (2009): 367-92, p. 391.

${ }^{31}$ We should be careful not to confuse the standard of consent introduced here with the absence of voluntary consent that I have argued characterizes the state-bank insurance relationship. It is because the latter relationship is not voluntary that those forced to contract - the state on behalf of its citizens and the banks - should conclude a contract that both can endorse. The coercive nature of the relationship raises the demand for reciprocal justification.
} 
clude a contract that allows risk-taking up to the point where the expected social benefits of an additional unit of risk would be offset by the expected social costs. This economic formula stresses that we are looking for an optimal level of risk-taking, from the aggregated vantage point of all parties involved. ${ }^{32}$ The question is how to operationalize this idea. It seems to me that the diverse nature of the considerations involved makes it very hard to quantify these in a neat way. For example, Mehrsa Baradaran has recently argued in a very perceptive analysis that an implicit social contract between U.S. citizens and banks has existed, which involved three major components: (1) safety and soundness, (2) consumer protection, and (3) access to credit. ${ }^{33}$ All of these and other considerations deserve debate. My purpose here is not to be conclusive about how such considerations would need to be weighed in bringing about such a social contract, but rather the more modest one of opening up the space for these considerations.

In the next section, I will turn to a retrospective evaluation of the financial crisis, in order to generate some conclusions that seem to me pertinent in thinking about the content of a prospective social contract as well. This section has made space for the conclusion-against the standard argument - that banks may violate a moral obligation, namely, when they exceed a socially acceptable risk level. The retrospective question is: did they? Or did citizens simply accept, even push for, an excessive risk level themselves? ${ }^{34}$

\section{A Contractualist Approach to the Financial Crisis}

The contractualist standard suggests that to determine whether the excessive risk-taking in the run-up to the 2008 financial crisis was acceptable to all those involved, we need to investigate the implicit expectations between citizens/taxpayers and bankers. ${ }^{35}$ The crisis cannot be wholly

\footnotetext{
${ }^{32}$ I thank an anonymous reviewer for suggesting this formula.

${ }^{33}$ Mehrsa Baradaran, "Banking and the Social Contract," Notre Dame Law Review 89 (2014): 1283-342.

${ }^{34}$ In this section I have tacitly equated two different ways of operationalising the social contract: as calling for a 'politically determined risk level' and as calling for a 'socially acceptable' risk level. These correspond to two traditions in social contract theory, that of actual consent (through an actual political process) and hypothetical consent (as a matter of moral theorizing). This raises difficult questions about the authority of moral theory vis-à-vis democratic processes, although in the end I do not think these are incompatible. Moral theory is best conceived not as a competitor to, but as part of the democratic process. In that way, the analysis in section 4 aims to illustrate how actual citizens may think and politically act with respect to the future acceptance of the risks related to banking.

${ }^{35}$ Ned Dobos, "Neoliberalism: Is This the End?" in Dobos, Barry, and Pogge (eds.),
} 
blamed on banks if they could have reasonably interpreted citizens as allowing (or even encouraging) excessive forms of risk-taking, that is, if the relevant social and political institutions operated on the assumption that such risk-taking is socially desirable for all. By contrast, if these institutions did not legitimate high risk-taking, then banks' behavior can be interpreted as a violation of the social contract. Assessing the implicit stance of "society" is a difficult, inevitably somewhat speculative matter. The best way to proceed is to look at the more structural causes of the crisis, that is, to go beyond the familiar list of immediate causes (government deregulation, central banks' expansive monetary policy, banking innovations such as securitization and subprime lending, rating agencies' activities, and so on). Several analyses have been given of these more structural causes of the crisis. ${ }^{36}$ Here I will take my lead from Wolfgang Streeck's analysis.

Streeck interprets the recent crisis as a crisis of "democratic capitalism. ${ }^{37} \mathrm{He}$ argues that democratic capitalism is an inherently explosive combination of two competing normative principles. On the one hand, capitalism requires the allocation of goods on the basis of free market forces, legitimized in a notion of merit. On the other hand, there is a democratic principle of allocating goods on the basis of entitlement, as decided by democratic procedures. The conflict is between democratic majorities asking for redistribution and capitalist forces that want the market to operate without impediments. This conflict can be mitigated when there is economic growth, for then both parties experience a gain. Streeck's suggestion is that after the 30-year postwar period of strong growth, the developed world has experienced three crises of democratic capitalism, the financial crisis being the last one. All of these crises came about because of the democratic public's demands for economic growth in times when it was unavailable. As Streeck argues, "more than two decades of uninterrupted economic growth had resulted in deeply rooted popular perceptions of continuous economic progress as a right of democratic citizenship." 38

The first crisis was the inflation crisis of the 1970s. Key to this phase is that a strong welfare state had been built, governments were committed

Global Financial Crisis, chap. 4, p. 76.

${ }^{36}$ See, e.g., Stefano Zamagni, "The Lesson and Warning of a Crisis Foretold: A Political Economy Approach," International Review of Economics 56 (2009): 315-34; Colin Crouch, The Strange Non-Death of Neoliberalism (Cambridge: Polity Press, 2011); Roemer, "Ideology, Social Ethos and the Financial Crisis."

${ }^{37}$ Wolfgang Streeck, "The Crisis in Context: Democratic Capitalism and Its Contradications," MPIfG Discussion Paper 11/15 (Max Planck Institute for the Study of Societies, 2011).

${ }^{38}$ Ibid., p. 6. 
to full employment, and trade unions were in a strong position. As a consequence, they pushed for wage increases beyond productivity growth. The only possible reaction on the part of government was to accept rising inflation. This policy was overturned in the 1980 s, when central banks reduced inflation (by raising interest rates) and the Thatcher and Reagan governments accepted unemployment and broke the power of the trade unions. This marked the beginning of the second crisis:

With inflation no longer available for closing the gap between the demands of citizens on the one hand and of "the markets" on the other, the burden of securing social peace fell on the state and on public finance. ${ }^{39}$

Thus public debts exploded from the 1980s until the early 1990s, when the Clinton government was determined to overturn the trend and consolidate the state budget. This strategy of public debt reduction, however, was accompanied by deregulation of the financial sector:

Rapidly rising income inequality caused by continuing de-unionization and sharp cuts in social spending, as well as the reduction in aggregate demand caused by fiscal consolidation, were counterbalanced by unprecedented new opportunities for citizens and firms to indebt themselves. ${ }^{40}$

It is worth quoting Streeck's conclusion of this process in full:

Toleration of inflation, acceptance of public debt, and deregulation of private credit were no more than temporary stopgaps for governments confronted with an apparently irrepressible conflict between the two contradictory principles of allocation under democratic capitalism: social rights on the one hand and marginal productivity, as determined by the relationship between supply and demand, on the other. Each of the three worked for a while until they began to cause more problems than they solved, indicating that a lasting reconciliation of social and economic stability in capitalist democracies is no more than a utopian project. Eventually, all that governments were able to achieve in dealing with the crises of their day was to move them to new arenas where they reappeared in new forms. There is no reason to believe that the successive manifestations of the contradictions inherent in democratic capitalism in ever new varieties of economic disorder should today be at an end. ${ }^{41}$

I will assume, if only for the sake of argument, that Streeck's analysis about the structural origins of the financial crisis is roughly correct. Those who disagree with Streeck may at this point fill in with their (slightly) different analyses. The point here is that something like such a sociological account is necessary for the ethical analysis mentioned in the previous section, that is, assessing the implicit social contract between

\footnotetext{
${ }^{39}$ Ibid., p. 11.

${ }^{40}$ Ibid., p. 12 .

${ }^{41}$ Ibid., p. 18.
} 
banks and society. Following Streeck's analysis, the contract would rest on two key variables: popular expectations of growth and the distribution of the fruits of growth.

Expectations of growth can be reasonable or inflated. ${ }^{42}$ A person's expectation of growth relates to the growth of his personal level of income and consumption. This expectation is reasonable if it can be fulfilled given a society's overall level of economic growth. A reasonable growth expectation is higher when the economy is growing fast, and lower when it is growing more slowly (or negative in an economic downturn). For a growth expectation to be reasonable, the micro-level has to match what can be realistically satisfied given the macro-development of the economy. The economy's long-term growth path depends on the growth of labor productivity. Normally such growth will be higher in earlier stages of economic development and lower in later stages of development. Annual growth of 8 to 10 percent per year is realizable when a country is industrializing (like China today) but unrealistic in developed economies. Streeck's account gives reason to think that popular growth expectations after the golden decades (1945-1970) were unrealistic.

To the extent that popular expectations of growth were inflated, and this made for a political push to deregulate finance, then citizens can be held responsible for endorsing a highly risky social contract. The banks' response to this (by creating financial products with excessive risks) is not free from blame either; but it does take two to tango. By saying that they agreed to a highly risky contract, I do not claim that the parties were aware of the highly risky nature of this contract before this became apparent in 2008 (although some individuals were). In law, when attributing responsibility for damages, a distinction is made between a fault model and a liability model. ${ }^{43}$ With respect to the risks involved, citizens and banks did not know better and did not - for the most part - intend to cause the damage that was done. Still, with hindsight, we can still say that they should have known better, or at any rate that they can be held liable for the damage (this conclusion is subject to some important exculpating factors that I mention later in this section). Collectively they have bet on the high returns of a system of finance that promised to offer the majority

\footnotetext{
${ }^{42}$ I leave out of consideration difficulties pertaining to the identification of growth expectations. Since these cannot be directly empirically observed, one must infer the existence of such expectations from the actions of individual citizens, and possibly the political actors representing them. Of course this is far from straightforward-Streeck's sociological narrative requires much more precise evidence to establish his claims about popular growth expectations.

${ }^{43}$ Iris Marion Young, "Responsibility and Global Labor Justice," Journal of Political Philosophy 12 (2004): 365-88, p. 368.
} 
of the population a way to "escape the tyranny of earned income."

An assessment based on growth expectations, however, assumes that the fruits of growth are distributed fairly. I will not take a stance on what a fair distribution of income and wealth would be. The general intuition is that everyone has to receive a share, so that growth benefits society as a whole. ${ }^{45}$ It should not just be a small elite that captures the lion's share of a country's growth. To the extent that large parts of the population are not being given their fair share, it is understandable - even if economically unwise - that they try to compensate for this by claims on the government (stimulating public debt) or on the future (by asking for access to credit). In this case, the burden shifts to those who lobby against a fairer distribution of income and wealth. Even if bankers themselves (defined as a professional group) would be part of this group, arguably they cannot be the whole of it. Rather, one would have to point to those privileged social classes who are able to influence political decision-making to prevent a more equitable distribution of income and wealth. ${ }^{46}$ This standard may lead to different conclusions depending on the country under consideration. Arguably, in the U.S. both the facts of stagnating real wages over decades (while there was growth) and the distorting influence of money on the political process have caused an unfair distribution of income and wealth. It needs to be noted, however, that for some other societies that have engaged in more adventurous forms of banking (from Iceland to Ireland, from Greece to Cyprus), this exculpating factor may be absent. Then all the weight falls on the factor of inflated growth expectations.

There is one important qualification to the analysis in this section, which assumes that citizens can be held responsible for their growth expectations (absent unjust inequalities). A full analysis would have to inquire in more detail how such expectations are formed. For example, it may turn out that one very important cause of inflated growth expectations is a process called "positional competition." 47 People strive for higher levels of income and consumption to keep up with the rising standard of living in society ("keeping up with the Joneses"). ${ }^{48}$ On a dif-

\footnotetext{
${ }^{44}$ Julie Froud, Sukhdev Johal, Johnna Montgomerie, and Karel Williams, "Escaping the Tyranny of Earned Income? The Failure of Finance as Social Innovation," New Political Economy 15 (2010): 147-64.

${ }^{45}$ One justification for this is Rawls's difference principle. See John Rawls, A Theory of Justice, revised ed. (Oxford: Oxford University Press, 1999).

${ }^{46}$ Here the evidence given by Thomas Piketty is relevant. See his Capital in the Twenty-First Century (Cambridge, Mass.: Harvard University Press, 2014).

${ }^{47}$ Fred Hirsch, Social Limits to Growth (Lincoln, Nebraska: iUniverse.com, 1999).

${ }^{48}$ To make matters more complex, inequality may be a major factor in stimulating these forms of competition: in a more unequal society, anxiety about social status is higher
} 
ferent level, citizens may have been unable, due to the complexities of financial products, to make well-informed decisions about the level of risk they are willing to accept, and financial providers may have exploited this lack of knowledge. These and other political and economic pressures may have played a complex role in the formation of growth expectations. All of these may lead us to exculpate citizens from (part of) their responsibility for their growth expectations, or at least think in a nuanced way about "who caused" and "who is to blame for" this process of inflated growth expectations. ${ }^{49}$

A full analysis of these dynamics of growth expectations and inequality is beyond the scope of the present paper. However, my purpose in this section was the more modest one of showing how the ethical standard introduced at the end of the last section might be operationalized; that is, how a consideration of the structural causes of financial crisis is necessary to assess the implicit social contract between banks and society in recent history. Reasonable growth expectations are important, as much as a fair distribution of whatever growth is realized. This is important retrospectively, for it helps us judge whether the financial crisis is a case of banks violating the implicit social contract with citizens, or instead a case of citizens and banks together endorsing a social contract that promised high returns to both (forgetting the high risks attached). These factors are equally important prospectively, in determining what the social contract between banks and citizens should be in the near future. Banks should refrain from violating any social contract, whatever its content; if citizens acting collectively decide that the banking sector should structurally lower its risk levels, this should be respected. Whether risk levels should indeed be lowered, depends on structural factors such as those discussed in this section, which go beyond narrow considerations of banking alone.

\section{Conclusion}

This paper has sought to uncover the moral logic implicit in the relationships between banks, states, and citizens, as they became evident through the bailouts of banks in the recent financial crisis. I have argued that these relationships can best be understood as insurance relationships: states need to insure banks against the systemic risks that banking entails. The need to do so is itself grounded in a fundamental right, not of banks, but

as well. Richard Wilkinson and Kate Pickett, The Spirit Level: Why Equality Is Better for Everyone (London: Penguin Books, 2010).

${ }^{49}$ Another qualification is that a more fine-grained analysis may need to talk less monolithically about "citizens" in general and distinguish different groups of citizens and their role in recent economic history. 
of citizens, to an adequate standard of living. This structure entails an inevitable tension. Citizens' fundamental rights require a system of rights and obligations, in which banks receive a right to be saved in exchange for an obligation not to put themselves in a situation in which this becomes necessary. This obligation is interpreted as an obligation not to impose risks on citizens if the latter have not endorsed these as part of a reasonable social contract. However, the banks' right to be saved must be honored even where they have violated their obligations. The ensuing conflict can only be resolved if states use their coercive power to regulate and monitor banks to prevent violations of the social contract. In this way, economic, moral, legal, and political considerations are intertwined. The most difficult question is what a reasonable social contract between banks and society would look like. In the final part of the paper, I have attempted to show that this depends on a much wider economic context: justice in the distribution of wealth, and reasonableness in popular expectations of economic growth. The recent financial crisis prompts us to consider these controversial issues more closely. ${ }^{50}$

Department of Philosophy \& Religious Studies, Utrecht University

r.j.g.claassen@uu.nl

\footnotetext{
${ }^{50}$ I would like to thank two reviewers for this journal for their very helpful comments. Further, I would like to thank Marcus Düwell, Lisa Herzog, Pietro Maffettone, Marco Meyer, Linda Senden, and Nicholas Vrousalis for their written comments on earlier drafts. I also thank audiences at the Utrecht/Cambridge Workshop, "Rethinking the Foundations of European Financial Market Regulation and Enforcement," April 2013, and the Economic Ethics Network Meeting, July 2014. This work was supported by a VENI-grant from the Netherlands Organization for Scientific Research (NWO).
} 
Copyright of Social Theory \& Practice is the property of Florida State University, Dept. of Philosophy and its content may not be copied or emailed to multiple sites or posted to a

listserv without the copyright holder's express written permission. However, users may print, download, or email articles for individual use. 